\title{
Tapping into the 'standing-reserve': a comparative analysis of workers' training programmes in Kolkata and Toronto
}

\section{Saikat Maitra ${ }^{1}$ \& Srabani Maitra ${ }^{2}$}

Abstract: This paper examines employment-related training programmes offered by state funded agencies and multinational corporations in Toronto (Canada) and Kolkata (India). In recent years both cities have witnessed a rise in the service sector industries aligned with global regimes of flexible work and the consequent reinvention of a worker subject that is no longer disciplined according to the needs of industrial production. A worker must now be selfregulated, competitive, flexible, with an ability to convey an urbane, English-speaking deportment within the workplace. Training of employees, especially soft skill training becomes crucial in this connection as a form of technology for achieving this end. Based on Martin Heidegger's conceptualisation of 'standing reserve', we suggest that what training programmes do in the context of neoliberal capitalist production is the creation of an essential quality of human-ness that has to be harnessed, its potentialities tapped and amplified through training. We further suggest that such programmes often remain heavily influenced by race/class/gender hierarchies as well as stereotypical assumptions of desirable/undesirable bodies, forms of socialisation and modes of habitation that often are naturalised in the course of training.

Keywords: adult learning; workplace training; soft skill; immigrant; neoliberalism; service sector

\section{Introduction}

Toronto, as a 'First World' city and hub of financial capital, stepped into the realm of neoliberal economy in the late 1980s when Canada shifted from its earlier Keynesian welfarism to a market driven economy. This shift was marked by the dwindling of social safety nets and a rise in service sector jobs that were often temporary and contractual, leading to a highly competitive, volatile and precarious labour market (Boudreau, Keil, and Young 2009; Walks 2014). Kolkata, one of the largest cities in India, on the other hand, had a long history of socialism and state planned urban development before the 1990s, when the Communist Party of India (Marxist) - CPI(M) - government began to view economic liberalisation as critical for improving the city's conditions of 'Third World' poverty (Hutnyk 1996). For both cities, the insertion into global flows of corporate capital and market-driven economies from earlier models of welfarism or socialism has been accompanied by the collapse of older manufacturing

\footnotetext{
${ }^{1}$ Department of Anthropology, University of Texas at Austin, Austin, TX, USA

${ }^{2}$ Department of Equity Studies, York University, Toronto, ON, Canada
} 
and industrial bases as well as a decline in long-term and secured employment, especially for the economically vulnerable sections of the urban populations. Concurrent to this process of de-industrialisation, both cities have witnessed a parallel rise in the service sector industries aligned with global regimes of flexible work and the consequent re-invention of a worker subject that is no longer disciplined according to the needs of industrial production (Foucault, 1990). A worker must now be self-regulated, competitive, flexible; often with an ability to convey an urbane and cosmopolitan deportment within the workplace.

Various employment related training programs (ETPs), provided by state sponsored agencies as well as transnational corporations now increasingly mould the labour force in the two cities to the requirements of global service capital by regulating and controlling the workers' speech, forms of social interaction and bodily appearances to craft the 'ideal' neoliberal worker-subject. For instance, in Toronto, training programs are provided by government sponsored settlement agencies to prepare immigrants-especially immigrants of colour - for the Canadian labour market. Much of this training is about teaching immigrants certain soft, relational and interactional skills that are easily transferrable, and presumably desired by Canadian employers (Jackson 2005; OMCIIT, 2012). Training curricula are thus geared towards improving immigrants' communicational skills, adaptability, team-working capacities, behavior, flexible attitudes, as well as understanding of Canadian culture, values and norms (Guo 2009; Sparks and Butterwick 2004). Immigrants, too, are usually eager to learn these skills, often trying to re-imagine their racial and cultural identity in the process, hoping that this might substantially increase their chances of accessing the labour market $(\mathrm{Ng}$ and Shan 2010). 
Similar to contemporary capitalist transformations in Toronto, Kolkata too has seen a prominence in privatised training programs allied with its post-industrial service economy (such as retail, entertainment, hospitality) over the last decade. In accordance with the Indian national skill policies to develop workers who are flexible, adaptable, and adept in behavioural, inter-personal and inter-functional skills, the local government in Kolkata has engaged in dialogues with the World Bank and other private institutions to provide effective, demand-driven and inclusive skill training to its workforce (Goel 2009; PFPL 2012). Consequently, private retail and service sector corporations, with their in-house ETPs are gradually taking over the state's prerogative for training and developing workers to fulfill their urgent requirement for a more malleable and flexible workforce that can adapt quickly to the changing nature of jobs in these upcoming sectors. However, most workers in Kolkata entering the entry-level jobs in service industries, like in the hospitality sectors or organised retail outlets, are from working class or poor families and struggle to strike a balance between the professional imperative to present themselves as global cosmopolitan subjects and their actual realities of low income, diminishing job securities and marginalised backgrounds.

ETPs critically try to fill in this void between the requirements for presenting workers as global, consumer subjects and the realities of social precariousness that most workers struggle with. This is where the need for re-making the subject characteristics of the workers achieves a critical density. ETPs aim to repeatedly impart training to workers to re-create them as resilient subjects, who can survive the ever shifting terrains of contractual service jobs, constant anxieties about job loss and extreme financial or social insecurities and yet, continuously provide service with a smile within the affluent environments of a shopping mall or a café. Moreover, trainings are expected over time to effectively bridge the disjuncture between workers' Bengali speaking, familial life worlds and the idiom of an 
unfamiliar, English speaking global cosmopolitanism through language, gesture and comportment.

Informed by Martin Heidegger's notion of 'standing-reserve', this article comparatively explores the formation of particular forms of worker subjects - mostly among vulnerable populations in the two city spaces, Toronto and Kolkata - who are increasingly essential as cheap and disposable labour for the functioning of the emergent, post-industrial service industries in the two cities under considerations. Along with Heidegger, we also draw on Michel Foucault, to situate 'subject' formation as a dual process - being subjected to "someone else by control and dependence, and tied to his (sic) own identity by a conscience or self-knowledge" (Foucault 2000, p. 326). As Foucault goes on to explicate, these parallel processes hinge on the utilisation of power to create pathways and technologies for moulding particular persons into particular categories of subjects. Simultaneously, the person internalises the necessary mechanisms of control including developing a critical selfreflexivity to the process of subject formation. Therefore, in their fullest sense, what ETPs strive to achieve are to create a set of technologies, forms of disciplines, social ideals and visions of the human body/mind that make transparent "what it is to be a human being" at least in so far that it is the ideal of the human being that is most desirable from the view-point of capitalist extraction of labour (Dean 1995, 566).

\section{Harnessing 'Human Nature'}

In his celebrated essay 'The Question Concerning Technology', Heidegger suggests that 'the essence of technology is by no means anything technological' $(1977,4)$, but rather such an essence inheres in the 'setting-in-order', 'challenging' and 'setting upon' of nature as 
a continuous store of energy and of resources that must be made to yield itself to the technological manipulations of man. Thus, nature becomes in Heidegger's terminology a 'standing-reserve' of technology linked to industrial capitalism (especially of the nineteenth and early twentieth century experiences of industrial capitalism), which draws its life-blood of resources, forms of energy and vitality from this inexhaustible domain through ordering and extraction. The natural landscape is from this essence of technology, a striated zone of mineral resources, of coal-fields for example, that must be extracted through technological means, converted into energy in order to drive the turbine in a factory and so on:

[t]he setting-upon that challenges forth the energies of nature is an expediting...It expedites in that it unlocks and exposes. Yet that expediting is always itself directed from the beginning toward furthering something else, i.e., toward driving on to the maximum yield at the minimum expense (Heidegger 1977, 15).

Thus nature becomes a zone of extraction done in the most cost-effective manner possible. However, writing in the $20^{\text {th }}$ century, Heidegger cautions us to something else that is enmeshed within this domain of nature that is outside the cultural-technological calculation which must be mastered, controlled and made the 'standing-reserve' for interventions. Heidegger (1977) writes,

Only to the extent that man for his part is already challenged to exploit the energies of nature can this ordering revealing [of nature as a field of extraction] happen. If man is challenged, ordered, to do this, then does not man himself belong more originally than nature within the standing-reserve? The current talk about human resources...gives evidence of this (18). 
Therefore, in this phase of late capital, how does human-life become naturalised as a domain of intervention that can be manipulated as resource, or ordered to be on reserve for the extraction of value, is a theme we wish to pursue. To take the geological metaphor further, how does the various strata in human nature allow the extraction of potential labour and profit? Moreover, what are the ways in which such nature can be created, harnessed and made to unfold itself as and when necessary? Taking up Heidegger's analogy of how technology ultimately reduces and frames nature as a reserve, for instance, of coal trapping energy that can be transformed into multiple other forms, neoliberal capitalism in the present, increasingly attaches itself to an understanding of life as a circumscribed field for the extraction of value. In such a category of thought, the forms of social life, the vitality inherent in the prospective worker can be drawn on for the purpose of value extraction. As Gorz (2010) argues,

What companies regard as 'their' human capital is, therefore, a free resource, an 'externality' that produced itself and continues to produce itself, while companies merely tap into and channel its capacity to produce itself. This human capital is clearly not purely individual. The production of self does not happen out of nothing. It takes place on the basis of a shared culture transmitted by primary socialisation and common forms of experiential knowledge (11-12).

Just as nature with its striations of coal-fields or mineral deposits are framed as an externality to be utilised (in the most cost-effective manner possible) for industrial manufacturing, increasingly, 'human-nature' with its own striations of social skills, communicative capabilities or emotional categories provide the field for extracting resources today for much 
of post-industrial service economies. Here, Foucault's governmentality approach enables us to shed further light on the management, extraction and exploitation of human nature within the neoliberal economy. Foucault defines governmentality as a set of techniques and procedures for directing human behavior and underscores that the process includes certain modes of training and modification of individuals, "not only in the obvious sense of acquiring certain skills but also in the sense of acquiring certain attitudes in living out life" $(1988,18)$. We identify ETPs, geared towards workers' soft skill development, as a form of governing strategy that emphasise the potentiality of human capacities inherent in each worker that needs to be controlled and channelised for the purpose of being a productive subject. Here training programs act as to "[designate] the way in which the conduct of individuals or of groups might be directed" within a larger field of various possibilities to fashion the most productive dispositions necessary for success in the neo-liberal labour market (Foucault 2000, 341). What is fostered through training are the characteristic traits, understood as natural and latent in every human being, which can be cultivated to become means of surviving a precarious and flexible labour market. Thus training programs are often circulating mediums of subject formation demanded by the imperatives and contingent conditions of capitalist development across the globe.

Costea, Crump and Amiridis (2007) further explain such attainment of attitude and skills through their conceptualisation of therapeutic habitus. Following Foucault, they argue that neoliberal worker management strategies are no longer coercive or authoritative. Rather, workers are governed into engaging in continuous self-management and self-inspectionwhat Foucault defies as technology of the self. Through various wellness and well-being programs and training, workers are thus regulated to "strive continuously to mobilise untapped inner resources [within themselves] to overcome limitations in the pursuit of ever more "excellence"" within the workplace (Costea, Crump and Amiridis 2007, 5). It is the 
potential worker who must engage in self-improvement whereas training provides a suitable template for helping the worker-subject unlock the hidden resources of his/her own nature.

The effectiveness of governementality, therefore, inheres in making labouring subjects believe that they should continuously take care of the self and enhance personal values. They should strive to develop latent capabilities for empowering themselves and realise their unlimited potential as human resource. It is only then that they can ensure excellence in performance and lead organisations towards success, rather than yardsticks of success or failure imposed on them externally. Governing strategies thus operate within a framework of freedom, choice, agency and autonomy where workers are subtly made to accept that they need to be self-responsible, "account for their own lives" and maximise their lives "as a kind of enterprise" (Rose, O’Malley and Valverde 2009, 12). Workers participate in this self-scrutiny and self-governance, to improve themselves and gain "unlimited fulfilment" and "personal achievement" (Costea, Crump and Amiridis 2007).

\section{Method}

The discussions in this paper are based on two qualitative studies ${ }^{\mathrm{i}}$ aimed at examining how soft skill training modules under ETPs, surveillance techniques and conduct manuals work at tandem to craft a particular labouring subject under neoliberal regimes. The city of Toronto and Kolkata were chosen as sites for research based on the fact that Toronto is a key entry point for many new immigrants, especially immigrants of colour. The infusion of cheap labour pools in the form of immigrants of colour is partly responsible for the survival of the low-end service sector in Toronto despite drastic restructuring. Kolkata too has a huge pool of socially marginalised workers belonging to low income groups, who are usually employed in the new retail spaces and other low end service industries (Gooptu 2009). Thus, both Toronto and 
Kolkata are important sites to map the scripting of worker-subject in relation to restructuring and employment related training programs.

Beginning in April 2010, the first author as part of his doctoral research conducted an eighteen month ethnographic fieldwork as a floor-level worker in a food-based retail chain Globofood (pseudonym) - in one of the largest malls in Kolkata, India. He structured his data collection efforts into two phases: 1) Participant Observation: Working as a junior salesperson at the South City Mall, the largest shopping mall in southern Kolkata, the first 3-4 months of field work utilised participant observation as his primary research method to build formal and informal relationships with co-workers and managerial staff. This phase served as an intense immersion in the everyday processes of work, communication skills in English, forms of training and comportment characterising employees at this institution. He also focused on studying how the institution crafts idealised worker subjects through repeated training modules, surveillance techniques, labour regulations, manuals specifying worker conduct etc. 2) Interviews: The interview phase built on and augmented knowledge gleaned through participant observation. He interviewed two sets of individuals. a) Key-Informants: He conducted semi-structured interviews with 10 employers, trainers, and developers associated with organised retail industries in Kolkata. Interviews drew on knowledge of Kolkata's retail industry earned through participant observation. b) Workers: He conducted semi-structured interviews with 40 individual workers (both men and women). Through the interviews the second author primarily explored the training experiences of the workers and their responses to the training modules.

Most of the workers interviewed had at least high school education with a few holding University degrees (B.A. or B.Com) as well. They were between the ages of 20-25, primarily unmarried and have been working in the mall for at least 1 year. The workers were from low income/poor families with parents working as farmers, small shop keepers, domestic helpers 
and in few cases low level clerks. The trainers interviewed for the project were all Graduates with MBA in Business or Human Resource from reputed Management institutions in India. The managers were fluent in English, Hindi and Bengali and have been working as corporate trainers for the past 3 years.

Beginning in June 2011, the second author, as part of her SSHRC funded Postdoctoral research interviewed 10 key informants such as coordinators, employment counselors and program instructors in various government funded organisations in Toronto that provided employment related training to immigrants. Interviews were also conducted with 25 South Asian immigrant women enrolled in various employment related programs aimed at improving workers' soft skill abilities. All the interviewees were highly educated with University degrees primarily in Science and Commerce. A few were Arts graduate. Prior to coming to Canada these women had worked in various non-regulated professions such as information technology (IT), banking, management, business administration, marketing and sales. In Canada, the term 'non-regulated profession' refers to jobs that do not legally require certification, registration or licensing. For members of some non-regulated professions, certification/registration with a professional body is available on a voluntary basis (CICIC ${ }^{\mathrm{ii}}$ ). Scholars argue that, lack of formal, uniform criteria for non-regulated professions, pose complicated but often subtle challenges for immigrants making a transition from their previous jobs and designation to those available in the destination country (McCoy and Masuch 2007). After migrating to Canada the women interviewees were also unable to find jobs in their own fields. Consequently they enrolled in career development programs (e.g. Bridge training) and workshops (e.g. job search workshops, workplace language training) offered by government funded organisations to facilitate their entry into the labour market. Most of these training programs were geared at implanting within workers various soft skills 
such as communicational abilities, gesture correction, accent reduction and/or adaptability to prepare them for the Canadian labour market.

As part of the data analysis, both studies employed narrative analysis. Stories narrated by workers and management staff regarding their experiences of training were identified and compared to bring out relevant concerns pertaining to identity formation, employment habits and workers' agency. These stories were crucial elements in thinking about how workers visualised their own identities vis-à-vis the soft skills implanted in them by the trainers (Daiute and Lightfoot 2004). Such narratives were subsequently grouped under various headings based on repeated elucidations so that prominent themes and patterns of training experiences can be identified.

\section{Data Analysis: Production of the worker-subject through training}

\section{The Toronto scenario}

You know most of the immigrants who come from third world countries, they do not know the work culture here in Canada. The way they [immigrants] talk or the way they dress... I always tell them it is not going to get them job here. They are no longer in their own country. They need to learn the Canadian way...that is why training is so important.

This comment, made by an employment counselor of a government funded organisation in Toronto that offers various training programs for immigrants so that they can successfully enter the Canadian labour market, marks the category of the 'immigrant' as somehow radically 
different from the normative ideal of a Canadian citizen. The successful integration of a newly arrived immigrant, especially the immigrant of colour into the Canadian labour market, is indistinguishable from the process of imbibing the normative associations of a Canadian citizen-subject- an induction into Euro-Canadian norms and values (Bannerji 2000). As scholars such as Gorz (2010) have argued, present forms of capitalist work increasingly revolve around a huge investment of the worker's intellectual, social and cultural means of belonging such that becoming a worker is often inextricably tied to becoming a subject. This is, however, done not through the more coercive tendencies of inserting the worker body into monotonous routines of industrial or factory type disciplining. Trainers, with their emphasis on the level of ordinary living such as the style of dressing, ways of interaction, modes of greeting or workplace socialisation, replicate the gendered and racial assumptions of those who 'properly' belong to the normative community of Canadian citizens, in order to eradicate certain traits or cultural affiliations of immigrants of colour that stand in their way of assimilation. The following quotations from two employment counselors illustrate further how they try to socialise immigrants to what they consider as normative Canadian work culture,

I always tell them [immigrants] to practice small talk. That's...part of the Canadian workplace. They have to watch Canadian shows and know what is going on around them. If they are unaware or shy they cannot expect to be hired. When you are new in the country you have to learn the Canadian way.

I always mention in my workshops that workers need to be fresh and pleasant looking when going for their interviews. Sometimes people because of the way they cook sometimes smell of spices. So I always mention that take a shower and wear fresh clothes to the interview. Wear well-fitted clothes. You know some of them tell me in 
the workshops that clothes are expensive here. I tell them in that case go and buy a second hand one. You can get a cheap one in a second hand store. There's always a way if you are willing. Also shoes are important. Dress shoes with dress pants.

This reproduction of Canadian identity through modulation of the immigrant worker subject can operate only by an uncritical naturalisation of the forms of citizenship or the ideal subjectivity which anchors this citizenship where contentious issues of racial or cultural differences are from the beginning abrogated (Ong, 2003). What are foregrounded instead are a series of corporeal habits - taking a shower, dressing well, appearing confident and so on which taps into what is seen as a uncritical and generalised sense of 'Canadian-ness' that the immigrant can emulate or hope to emulate through incorporating the technologies of subject formation offered through the training. Questions about fundamental differences pertaining to race or gender or class are always subsumed under an emotional tendency that is flexible enough to learn and copy. Thus both the body and mind of the immigrant have to be harnessed through the training to stimulate a certain desire for upholding the normative subject of the labour market who is not moved by the structural hazards of racism or gender discrimination encountered in the course of everyday jobs. Moreover, the subject remains always on call ready to tide over a series of potential set-backs like job loss through her/his flexibility and resourcefulness. Thus, training the immigrant in Canada, especially the immigrant of colour, is not only about creating the possibilities for her/him to access the job market but is also and more fundamentally about preparing a particular form of the 'human being' who can be designated as a normative citizen-subject.

However, if citizenship is one of the ways in which the domain of life becomes integral for the crafting of an worker identity, training programs also inherently relate to qualities which 
are seen as internal or fundamental characteristics of all human beings, that nevertheless, must be evoked and heighted through training mechanisms. Trainers in Kolkata, often work with the assumption that while natural capacities for communication or social interactions are latent in all humans, the workers have to be 'governed' in the Foucauldian sense to heighten certain dispositions while dampening or reducing certain others to become a more productive human being. To highlight this function of training we turn to a small ethnographic vignette from the first author's fieldwork in a large food-based retail chain in Kolkata called Globofood.

\section{The Kolkata scenario}

The dimming of the lights raises the anticipation quite a bit, it is the thrill of the theater just before the film flickers on screen. 'Perhaps they will show Dabangg', Joyjit from the Electronics section quips, more as a joke referring to a recent high voltage Bollywood action film that most of the young workers at Globofood have seen more than once already. Then the screen comes alive, there are 3 short film snippets, rip-offs from the Discovery Channel or something similar. The first one is about a group of mountaineers struggling through icy weather along a cliff-side till one of them slips and starts hurtling down the rock face. It seems a sure death till a couple of his buddies grab hold of him and after some difficulty hauls him up. The second one is a reconstructed battle scene with a group of horsemen charging a much larger phalanx of opposing soldiers. Given the odds in number, the horsemen are initially reluctant to attack till the leader extorts them and leads from the front by galloping along all by himself. Soon the others join him and victory is achieved. Finally, the third one shows a lone athlete staggering through what looks like the end section of a marathon run. He is all but ready to give up, his close-up face a mix of streaming sweat, exhaustion, gasping breath. But he doesn't and manages to cross the finish line. Three events, three compositional scenes, which 
on the face of it seems to have little to do with what we have been doing for the last two days at Globofood.

There are 17 of us, 16 floor level employees drawn from various departments of Globofood, the largest food-based retail chain in Kolkata. Plus there is me, the researcher with the permission to do my participant observation routine as a regular worker in Globofood's Customer Service Desk. This is the second day of the Star II program - the more advanced training and up-gradation workshop that Globofood conducts for its floor level employees usually referred to as the CSAs or Customer Service Attendants. Globofood has a slogan for the top three qualities that it determines as crucial for retail work - All it takes is TLM - with TLM being the acronym for Team-work, Leadership qualities, Motivation or self-motivation to be more precise. The three clips screened generate visual metaphors for these intangible attributes, creating points of reference to which the trainee workers can come back as a stable set of references. These training programs depict the immediacy of certain tones of emotion, capacities and forms of interaction which effectively constitutes the terrain of work for an organisation like Globofood. Moreover, as a senior training manager at Globofood, pointed out, trainings emphasise to all the employees that they can succeed only when they love their work. Instead of viewing work as drudgery, something that employees have to do in order to earn a salary or because the managers might be angry with them, trainings serve to show employees how work in retail spaces is good because it brings out the best human potentials like social interactions or communications in workers. Manjit, the training manager, continued that trainings are most effective in not only showing workers how to perform certain functions well, but in suggesting to workers how those functions are critical in developing certain fundamental tenents of human nature latent in workers. It is only through work, that workers at Globofood can give the fullest expression to these otherwise repressed aspects of their human 
nature - like creativity or conviviality - and therefore must learn to love it for its own sake. In Manjit's words we see the strong emphasis placed on managing workers not through coercion primarily but to what Costea, Crump and Amiridis (2007) spoke of in terms a 'therapeutic habitus' of controlling workers through their own feelings of well-being and satisfaction attained in the realm of work.

The valorisation of work for the extraction of surplus value works therefore, through the continuous intervention on the terrain of life, of a generalised capacity to produce social skills where the main purpose of labour in the context of retail/service spaces is to evoke and communicate to the customer the passion or a taste for consumption (Hardt and Negri 2000). The management and control of feelings that workers learn through training are reminiscent of Hochschild's emotional labour, where she argues how workers often need to learn to suppress their feelings 'in order to sustain the outward countenance that produces the proper state of mind in others-in this case [airlines industry], the sense of being cared for in a convivial and safe place' $(2012,7)$.

On a similar vein we notice how in the context of Kolkata, each of the elements of team-work, leadership attributes and self-motivation become, therefore, the critical ways of interaction with customers, with other workers and with the environment of the retail space itself for the individual worker to produce the necessary 'feeling' of desire that induces the customer to buy. In this interactive paradigm of service labour, the focus of production is not decipherable in terms of the number of commodities produced per unit time, but ultimately production is impossible to separate or mark out from the re-production of the worker as a social individual bringing a host of social skills, communication practices, forms of interaction, 
local knowledge and so on. Training provides a mode of capturing this social reproduction and channelising it along particular circuits of what is desirable and what is not.

\section{Self-production as labour}

In analysing the training programs geared at socialising individuals to adopt certain soft skills, what was most significant was how through these programs the trainers often manipulated the desires, attachments and anxieties within workers, thereby governing them to internalise the practices deemed necessary to be a productive worker in the neoliberal labour market. In the Canadian context, for example, most of the immigrants interviewed for the project were highly educated with university degrees and professional experiences, who have come to Canada along with their spouses in expectation of an improved quality of life and socio-economic opportunities. However, given the gendered and racialised nature of the labour market that exists in Canada (Reitz 2004), none of the interviewees could get into a job that was commensurate with their previous educational or professional backgrounds. As one of the interviewees, a former bank employee from Bangladesh shared,

I had lot of expectations from immigration. I had thought I will get into my own field,

I will have a proper job, a career growth. But since the time I immigrated I have only been able to get into survival jobs in shops as cashier. I have had interviews for banking positions but I was never offered a job. Perhaps people don't want to hire immigrants like us.

One of the reasons, therefore, that the interviewees attended various training workshops, was with the hope of getting into 'proper' employment and connecting to the right network to 
facilitate their labour market entry. As one of the immigrant women who was a manager in a multinational company in India pointed out,

The first year I came here, I consistently kept on going to these community services organisations which claim that they have information of jobs, they assist you, new comers, immigrants with finding jobs. I have been to many organisations.

It was such feelings of hope coupled with uncertainty about their future prospects that were consistently manipulated throughout the various workshops to subtly regulate the worker subject to become more entrepreneurial and competent in Canadian workplace culture. Such manipulation was evident in how most of the trainers created within the immigrant workers a heightening sense of 'lack' and an 'urgency' to overcome such lack as essential to gaining employment. For example, one of the trainers from a settlement organisation mentioned during our interview that,

Here in Canada, soft skills are more important. Irrespective of your education, your appearance is more important. And I tell that to the immigrants looking for jobs. They have to learn how to adjust with a Canadian workplace, how to talk to employers, how to dress. Most of these newcomers don't know and I tell them unless you learn you will never get a job. Forget where you worked in your own country. Here in Canada you have to adapt to Canadian culture.

Pun Ngai, in her ethnographic study of the 'dagongmei', the transformation of rural women migrant workers into 'industrial bodies' $(2005,14)$ under the post-socialist conditions of state and capitalist forces in China, explains how this practice of constructing workers as 
deficient, serves the global capitalist interest of creating 'willing' labour. As the workers start to internalise their past lives and identities as deficient and incomplete, they end up conforming to self-subjectivisation. They do so because they want to overcome their 'lack', and want to successfully integrate 'into the collective will of the hegemonic construct' (Pun 2005, 114) so that they are not discriminated against. In case of the South Asian immigrants interviewed for the project, such discourse of 'lack' or 'deficiency' was hinted at by many trainers who consistently pointed out the necessity for immigrants to learn the socio-cultural norms of the Canadian labour market in order to be successfully employed. In the various training and information they received, rather than emphasising immigrants' present skills, competencies, customs or values, agency trainers consistently pointed out the need to be 'Canadian' in order to be employed successfully. As part of this Canadianness, most agencies emphasised bodily deportments and presentability as the key to preparing oneself for the job market.

Such training and modifications, therefore, are also instrumental in controlling the 'conscious subjective aspect of feeling and emotion' (Foucault 1978). Workers, however, are not forced to adopt such techniques of self-management but are 'encouraged' to adopt certain normative and hegemonic practices (Foucault 2008) in the name of soft-skill training. The drive to self-fashion their personas, means of socialisation and subjectivities are not achieved by any overt disciplining or coercive means. Rather the motivation to attain a particular workeridentity is made desirable so that the individual worker actively incorporates the ideals disseminated during training programs.

What is important to note here though that not all women felt equally 'encouraged' to socialise themselves to the Canadian ways. Rather, such discourses of lack or deficiency pointed out by counselors often also drove workers towards frustration and a sense of loss. 
Many thus pointed out how after repeated training programs failed to provide them with any 'proper' employment related to their own areas of expertise, they were often left with a loss of identity, a feeling of being suddenly becoming a 'nobody',

In all those agencies they just think we don't know English, we don't know work culture and that we have to be taught everything here. We are always seen as lacking.

When I came here I had to start from kind of scratch to live. I mean people don't take into account that I have already done a certain amount of work and I do have some experience. It may have been in another part of the world...but my experience doesn't have much value here. That's what disappointed me mostly. I have become nobody.

For most organised retail workers in Kolkata coming from often very under-privileged backgrounds, desirability is evoked by highlighting during training the ways of attaining a proximity to global cosmopolitan life-styles that work makes possible for the employees. By repeating the need for cleanliness, regular practices of hygiene including the use of deodorants or hand-soaps, the focus on a deportment that characterises the workers as part of a larger corporate identity, training programs seek to bring to the workers self-valorisation of their subjectivities based on their relationship to work. For instance the training manager Ajay informs me how hygiene is a top priority for workers deployed in the food and beverages category:

I take short courses with entry level employees and most of those sessions are informing them about certain routine hygiene. For example, I emphasise through training the need to wash hands with an anti-bacterial soap after every visit to the toilet, 
taking care not to sneeze or cough near the food items, to use deodorants regularly, shave and to shampoo the hair once every week at least.

He proudly notes that increasingly most employees are becoming aware about the need for hygiene and now all the hygiene products like hand-soaps, deodorants or shampoos that are past the expiry date in the store can be bought by employees at a discount. There is a large demand for these items and it benefits the store as well since all the excess stock is disposed off at a price instead of being thrown away. But as Nakul, one of floor-level employees observed, it is difficult to say whether hygiene was being promoted as a necessary quality for the well-being of the employees and the customers or it was seen to solve a major problem for the corporation - the disposal of excess stock items after their expiry periods:

I can understand about hygiene. It is important to be clean and smart to work in the mall. But sometimes we friends discuss whether they are selling us the products for our good or to make profit for themselves. After all, we only get the expired products most of the time. The good products are too expensive and we hardly get any discount on them.

Furthermore, all skills, from body language, communication, creative thinking or even the ability to crack a witty joke or be warm and affectionate in daily interactions can be usefully deployed for profits motives. As Sheela, the Chief Corporate Trainer in a Kolkata based retail company reminded the researcher, the crucial aspect that every employee is made to understand is that one has to be creative using all the resources that one has learnt in life. Every day experiences, for her, constitute the domain where one learns to be a good worker, to learn how to communicate ideas, how to listen and be attentive or how to resolve a difficult 
situation. So it seems that the conceptual category of work has turned a full circle, from devaluing and excoriating the traces of everyday life that could interfere and obstruct the full efficacy of productive time to fundamentally forming the substrate on which labour's profitability comes to depend on (Hochschild 2012).

As well, it is the everyday practices of work, how they speak, interact with customers or colleagues, inculcate habits of consumption like possession of cell-phones and so on that generate intimations of a class mobility that otherwise in more economic terms remain completely blocked for them. It is this liminal zone of performing certain traits of a more upwardly mobile class while remaining effectively denied from it that constitutes the basis of desire for these workers that training programs seek to manipulate and heighten. One of the corporate Vice-Presidents in charge of personnel at Globofood pointed out that the success at retail work depends on each worker being able to act as a manager - both managing her own potentials as well as working in tandem with the potentials of others thus constantly exhorting each other to perform better. Each worker-manager in turn must be like the Hindu deity Lord Vishnu holding in his four hands a conch, a lotus, a mace and a circular disc. The conch stands for effective communication, the lotus for harmonious team-spirit, the mace for maintaining order, and the disc as a sign for active involvement in all corporate matters. Thus, a worker would effectively assume the role of a successful corporate self. However, what kind of success is possible to realise for a worker even with all these 'divine' gifts is difficult to conceive given that basic monthly salary at Globofood for floor-level workers hovered around five thousand rupees or slightly less than $\$ 100$.

As post-industrial service economies develop globally, we highlight through above narratives how production as the main generator of value has expanded from utilising natural resources like minerals for instance and taking nature as the substrate from which value can be 
infinitely created through industrialisation to the self-production of subjectivities that can be utilised for profit-making purposes. To go back to Heidegger's provocative suggestion, 'human resources' has occupied the place of 'nature' as another domain that is readily available to be worked on, manipulated, adjusted and developed continuously to create specific modes of value extraction. Training of employees, especially soft-skill training becomes crucial in this connection as a form of governing technology for achieving this end. The social, communicational and emotional skills that individuals embody from the perspective of human resources thus become a second-order nature that is made available for extracting value. Yet, the extraction process has to be fine-tuned to adjust for specific forms of gender, class and racial discriminations operating in the labour market where only certain traits of social skills are recognised as suitable for putting into work while others must be depleted or otherwise modified. Thus a selective re-working of 'human nature' to adapt it for the requirements of post-industrial capitalism today becomes necessary.

\section{Conclusion:}

In this paper, we highlight how employee training programs with their emphasis on soft-skill training in the two diverse contexts of Kolkata and Toronto deploy certain governing strategies and principles to create specific kinds of laboring subjects allied with the demands of inter-personal, flexible and contingent nature of work in post-industrial service economies. Our goal in doing so is to suggest firstly, how through individuated training of often vulnerable sections of the urban population like immigrants of colour or underclass youth members, a larger labour force is being crafted that is disposable, low-cost and malleable enough to function in increasingly non-secure work-environments. Rather than being trained in particular sets of skills, the workers are taught to internalise a whole set of dispositions such as entrepreneurialism, communication skills, social interactions, self- 
resilience and ability to control/hide certain emotional traits such as anger or irritation. Secondly, these dispositions are routinely touted by trainers as fundamental units of human nature that all workers remain inscribed with. Yet, it is only through work, and when work is performed well, that these capabilities of human nature are essentially enhanced.

Thus work is to be viewed by workers, not as oppressive or disciplinarian, but as 'therapeutic' i.e. as the opportunity to enhance the potency of human nature. Drawing on Heidegger and Foucault's notion of governmentality, we suggest how the critical emphasis on 'human nature' under post-industrial work extends to the human capacities of workers the previous ideals of industrial capitalism, of a continuously exploitable earth, visualised as 'nature'. If the earth's nature remained striated with layers of resources, like minerals, the worker too remains striated with resources, like the capacity to communicate for instance, which must be harnessed, un-locked and more effectively utilised in the course of work. But if such utilisation is somehow blocked or failed, that is, if the worker fails to best put to work the hidden resources he/she carries as part of 'human nature', then that is attributed to the individual's own failure.

By naturalising success or failure as an innately individual venture, what training programs effectively does is to de-politicise the labour market completely. For instance in Toronto, where "immigrant credentials carry a penalty" (Li 2001, 20) the failure of highly educated, middle class immigrants to secure jobs in the formal labour market is no longer linked to issues of racism or gender discrimination structuring such a market. Rather, the failure to integrate in the market is seen to be the immigrant's failure to positively assimilate certain key qualities of human nature - such as being responsive to personal deportment, ability to communicate, and so on. 
Similarly, in Kolkata, the long colonial/post-colonial histories through which poverty and inequality are created in the city is elided to suggest that even the most under-privileged worker, in often dead-end jobs, can secure success by tapping into the hidden resources of his/her 'human nature'- by effectively capitalising these resources in the course of work. Despite the historical, social, economic, and geographical differences in the two locations of Toronto and Kolkata, we wish to emphasise how a set of techniques, discourses and material practices of subject formation, of which training programs are symptomatic for us, create particular kinds of workers allied with the imperatives and requirements of post-industrial labour today.

While individual trainers do try to impart the best possible skills necessary for workers to succeed in their work, whether in the context of Toronto or Kolkata, the ideological underpinnings of training programs based on assumptions about individual competencies or entrepreneurial nature as universal do not allow any critical self-assessment about the political implications of contemporary employee training programs. Moreover, given the ideological 'blindness' of current training regimes to structural issues like racism in the labour market or class hierarchies, trainers often a priori construe certain bodies - such as immigrants or working-class employees - as deficient. These bodies are then assumed to be urgently in need of corrective training where their own inherent social or communicative skills are seen as less than effective from the outset.

In view of these severe shortcomings of training programs, from policy perspective, we would like to suggest a more rigorous assessment of training programs conducted by settlement and corporate agencies that can situate the efficacy of such programs in actually bettering the lives of their participants. The trainers must themselves go through programs that can make them sensitive about the gender, racial or class hierarchies structuring the labour market whether in Toronto or Kolkata. A robust mechanism must be in place to see 
how effectively such objectives are being adhered to by private corporate partners in their bid to create a work-force. While we do believe that skill-training is critical for transforming often marginalised populations into productive subjects, it can only happen when such subjects are given the right opportunities and frameworks for persistent development and not made to languish as under-paid, disposable labour. In accordance with educationists such as Cruikshank, we, thus, would like to argue for an adult learning and training framework which "must go far beyond its current narrow focus of skills training for the new economy and must include a strong critical (civic) focus" $(2002,150)$.

\section{Bibliography}

Bannerji, H. 2000. The dark side of the nation: Essays on multiculturalism, nationalism, and gender. Toronto: Canadian Scholars' Press Inc.

Boudreau, J. A., Keil, R., \& Young, D. 2009. Changing Toronto: governing urban neoliberalism. Toronto: University of Toronto Press.

Costea, B., Crump, N., \& Amiridis, K. 2007. Managerialism and "infinite human resourcefulness": A commentary upon the "therapeutic habitus", "derecognition of finitude" and the modern sense of self. Journal for Cultural Research, 11(3), 245-264.

Cruikshank, J. 2002. Lifelong learning or re-training for life: scapegoating the worker. Studies in the Education of Adults. 34(2), 140-155.

Daiute, C., \& Lightfoot, C. 2004. Narrative analysis: Studying the development of individuals in society. California: Sage.

Dean, M. 1995. Governing the unemployed self in an active society. Economy and Society. 24:4, 559-583, DOI: 10.1080/03085149500000025.

Foucault, M. 1978. The history of sexuality: An introduction (vol 1). London: Penguine.

Foucault, M. 1988. Technologies of the self. In M. Foucault, L. H. Martin, H. Gutman \& P. H. Hutton (Eds.), Technologies of the self : A seminar with Michel Foucault. Amherst: University of Massachusetts Press.

Foucault, M. 1990. The History of Sexuality. Translated by Robert Hurley. Vol. 1. New York: Vintage Books.

Foucault, M. 2000. Power: The Essential Works of Michel Foucault 1954-1984 Volume Two, edited by James Faubion, translated by Robert Hurley and others, London: Allen Lane. 
Foucault, M. 2008. The birth of biopolitics: lectures at the Collége de France, 1978-1979 London: Palgrave.

Goel, V. P. 2009. Technical and vocational education and training (TVET) system in India for Sustainable Development. New Delhi: Minisitry of HRD, Government of India.

Gooptu, N. 2009 "Neoliberal Subjectivity, Enterprise Culture and New Workplaces: Organised Retail and Shopping Malls in India." Economic and Political Weekly 44(22), 4554.

Gorz, A. 2010. The immaterial : knowledge, value and capital. (C. Turner, Trans.) London ; New York: Seagull Books.

Guo, Y. 2009. Racialising immigrant professionals in an employment preparation ESL program. Cultural and Pedagogical Inquiry, 1(1), 40-54.

Hardt, M., \& Negri, A. 2000. Empire. Cambridge, Mass.: Harvard University Press.

Heidegger, M. 1977. The Question Concerning Technology. In M. Heidegger, The Question Concerning Technology And Other Essays (W. Lovitt, Trans., pp. 3-35). New York and London: Garland Publishing.

Hochschild, A.R. 2012. The Managed Heart. Commercialization of Human Feeling. Berkeley, CA: University of California Press.

Hutnyk, J. 1996. The Rumour of Calcutta: Tourism, Charity, and the Poverty of Representation. London: Zed Books.

Jackson, N. (2005). Essential skills, essential confusion. Literacies, 6, 38-43.

Li, P. 2001. "The Market Worth of Immigrant Education Credentials." Canadian Public Policy 27(1):2-38.

McCoy, L., \& Masuch, C. 2007. Beyond "Entry-level” Jobs: Immigrant Women and Nonregulated Professional Occupations. Journal of International Migration and Integration/Revue de l'integration et de la migration internationale, 8(2), 185-206.

Ng, R., \& Shan, H. 2010. Lifelong learning as ideological practice: An analysis from the perspective of immigrant women in Canada. International Journal of Lifelong Education, 29(2), 169-184.

Ong, A. 2003. Buddha is hiding: Refugees, citizenship, the new America. Berkeley and Los Angeles, California: University of California Press.

Ontario Ministry of Citizenship, Immigration and International Trade (OMCIIT). 2012. http://www.citizenship.gov.on.ca/english/keyinitiatives/imm_str/roundtable/recommendation s-settlement-and-integration.shtml

People Factor Pvt. Ltd. (PFPL). 2012. Skills Development in West Bengal: Opportunities and challenges: A consultation with private skills providers. World Bank, FICCI and Ministry of Technical Education and Training. 
Pun, N. 2005. Women factory workers in a global workspace. Durham and London: Duke University Press.

Reitz, J. G. 2004. Canada: Immigration and nation-building in the transition to a knowledge economy. In W. A. Cornelius, T. Tsuda, P. L. Martin \& J. F. Hollifield (Eds.), Controlling immigration: A global perspective (Second edition, pp. 97-133). Stanford, California: Stanford University Press.

Rose, N., O’Malley, O., and Valverde, M. 2009. Governmentality. Sydney Law School: The University of Sydney.

Sparks, B., \& Butterwick, S. 2004. Culture, Equity and Learning. In G. Foley (Ed.),

Dimensions of Adult Learning: Adult Education and training in a global era. Berkshire: Open University Press.

Walks, A. 2014. Stopping the 'War on the Car': Neoliberalism, Fordism, and the Politics of Automobility in Toronto. Mobilities, DOI: 10.1080/17450101.2014.880563.

\footnotetext{
' The research conducted in India was supported by the Wenner-Gren Foundation [grant number 8234]. The research conducted in Canada was supported by Social Sciences and Humanities Research Council [grant number 756-2010-0718].

ii http://www.cicic.ca/927//dentify-the-organization-responsible-for-recognition/index.canada
} 